\title{
Histochemical approach of the mobilization of reserve compounds in germinating coffee seeds
}

\author{
Leonardo Araujo Oliveira ${ }^{1}$, Genaina Aparecida de Souza ${ }^{(1 D}$, Bruno Tavares Silva ${ }^{1}$, Antônio Augusto Gomes Rocha ${ }^{1}$, \\ Edgard Augusto de Toledo Picoli ${ }^{(10}$, Diego de Sousa Pereira ${ }^{3}$, Sérgio Maurício Lopes Donzeles ${ }^{4}$ (B), \\ Marcelo de Freitas Ribeiro ${ }^{4}$, Williams Pinto Marques Ferreira ${ }^{5}$ (B)
}

\begin{abstract}
${ }^{1}$ Universidade Federal de Viçosa/UFV, Departamento de Biologia Vegetal, Viçosa, MG, Brasil ${ }^{2}$ Universidade Federal de Viçosa/UFV, Departamento de Engenharia Florestal, Viçosa, MG, Brasil ${ }^{3}$ Universidade Federal de Lavras/UFLA, Departamento de Agricultura/DAG, Lavras, MG, Brasil ${ }^{4}$ Empresa de Pesquisa Agropecuária de Minas Gerais/EPAMIG, Viçosa, MG, Brasil

${ }^{5}$ Empresa Brasileira de Pesquisa Agropecuária/EMBRAPA, Centro Nacional de Pesquisa do Café, Viçosa, MG, Brasil

Contact authors: leonardo.a.oliveora@gmail.com, genainasouza@yahoo.com.br, brunotavss@hotmail.com, antonio.augustoufv@gmail.com,epicoli@ufv.br, diegobizi@gmail.com, slopes@epamig.br, marceloepamig@gmail.com,williams.ferreira@embrapa.br
\end{abstract}

Received in January 16, 2020 and approved in June 24, 2020

\section{ABSTRACT}

The endosperm of coffee beans is an important structure which is composed of different reserve compounds. In the present study, we followed anatomical features during the reserve mobilization of Coffea arabica L. cv 'Catuaí' seed samples, harvested at 20 different sites, after 0 , 3, 6, 12, 24, 30 and 45 days of imbibition. Seed samples were properly stored for enzyme activity assessment and fixed in FAA solution (formaldehyde, acetic acid and ethanol, 1 ; $1 ; 18$ ) and kept in ethanol $70 \%$ solution, for histochemical analysis. Alternatively, samples for phenolic compounds histochemical test were fixed in Ferrous sulfate in formalin. Fixed samples were cross-sectioned for detection of starch, lipids, essential oils, oleoresins, proteins, phenolic compounds, neutral polysaccharides, alkaloids, $\beta-1,3$ and $\beta-1,4$ glucans, and lignin. Overall, based on histochemical tests and enzyme activity, seed reserve mobilization was similar among the evaluated altitudes and mountainsides. During soaking, there is an intense consumption of reserve compounds, starting at the region close to the embryo. Reserve mobilization intensifies after root protrusion, from 12 days of soaking. The intensification of the reserve consumption concomitant with an increased activity of $\mathrm{MDH}$ is observed at the first 12 days, whereas SOD showed higher expression after 30 days of soaking. At the $30^{\text {th }}$ day, little reserve is observed in the endosperm. At $45^{\text {th }}$ day, cotyledon leaves are expanded, and the root system, constituted by the taproot and lateral roots, is well established.

Key words: Coffea arabica; germination; reserve breakdown; histochemistry; seed anatomy.

\section{INTRODUCTION}

Coffea arabica L. belongs to family Rubiaceae with its center of origin in Ethiopia. Coffee seeds are flat-convex, elliptic or oval, and longitudinally grooved on the flat side and are composed by the embryo; the endosperm; and an envelope called "silver skin", which is originated from the integument.

Coffee seeds are obtained from mature fruits, called coffee cherries, and have irregular viability, slow and uneven germination (Reis et al., 2010). Delayed germination of seeds considerably extends the period of seedling formation process and may be attributed to properties of the seed cell walls and tissues, as well as to physical aspects such as endosperm hardness (Ferreira et al., 2018). The tissues surrounding the endosperm (micropylar endosperm) must be degraded (Zonta et al., 2010) so the radicle can then protrude and germination take place.

There are reports of the behavior of coffee seeds during germination (Carvalho; Guimarães; Silva, 2012; Farias et al., 2015), hormone effect (Da Silva et al., 2005; Da Silva et al., 2008) and imbibition pattern (Eira et al., 2006). Notwithstanding, there is little information on the anatomical and histochemical changes during germination process.
Germination starts with water absorption, yet its onset may vary depending on the species, seed coat permeability, water availability, temperature, hydrostatic pressure, contact area between seed and water, intermolecular forces, and seed chemical composition and physiological quality (Carvalho; Guimarães; Silva, 2012).

The endosperm is considered an important structure in the coffee bean constitution, both economically and physiologically (Goulart et al., 2007). It contains proteins, alkaloids, oils, sugars, dextrin, pentosans, cellulose, lipids, caffeine-derived acids, and other acids (Dedeca, 1957). The presence and proportion of each of these components are directly related to the production of more vigorous coffee seeds. Germination is a biochemical and physiological process that begins with water uptake by the seed and the activation of metabolism (Reis; Souza; Brito, 2020), as well as endosperm weakening which accompany further embryo development (Walters; Arendt; Moroni, 2017).

During the coffee seed germination process, protein hydration, respiration, cell elongation, and structural and enzymatic changes are reported before root protrusion (Selmar et al., 2006), as well as endosperm weakening which accompany further embryo development (Walters; Arendt; 
Moroni, 2017). With respect to the enzymatic changes in the role of dehydrogenase malate $(\mathrm{MDH})$ and superoxide dismutase (SOD) are highlighted (Assis et al., 2019). The enzyme malate dehydrogenase catalyzes the last reaction of the Krebs cycle (Tunes et al., 2011), being able to transfer electrons from their substrates to generate reduced NAD (P) $\mathrm{H}$ or $\mathrm{FADH}_{2}$, which then produce ATP via mitochondrial electron transport chain (He et al., 2019). This highlights a vital role in a variety of physiological activities, such as energy metabolism of mitochondria and ERO metabolism in plants (Heber, 1974; Jia et al., 2018), therefore, for the germinative process. While superoxide dismutase (SOD) acts by normalizing reactive oxygen species (ROS), which are generally harmful for cellular metabolism, mainly during seeds germination. Increased enzyme activity was observed in seeds and related to preparatory events for germination (Souza et al., 2018).

An effective mobilization of seed reserves and their degradation during seed germination are crucial physiological processes in the plant life cycle (Otegui et al., 2006). Accordingly, the aim of the present work study was to observe and describe the morphological and histochemical changes during germination process of coffee seeds harvested in different environments conditions as support for the ongoing research on the improvements of the coffee production system and beverage quality at the Matas de Minas region, Minas Gerais State, Brazil.

\section{MATERIAL AND METHODS}

\subsection{Seed sampling and acquisition}

Coffee seeds were collected at the Matas de Minas region (Southeast) of Minas Gerais State, Southeastern Brazil. Samples of Coffea arabica L. cv 'Catuaí' were collected at 20 different sites (Figure 1). Fruits were collected manually at stage 88 of the BBCH coffee scale, of complete physiological maturity (Arcila-Pulgarín et al., 2002). Additionally, to standardize the sampling procedures, the seed collection was performed at two altitudes: below $750 \mathrm{~m}$ (L) and above 900 $\mathrm{m}(\mathrm{H})$; and at two mountainsides: sun-exposed, with high light intensity (SUN), and shaded, with low light intensity (SHADE).

Twenty-four hours pos harvest, fruits were processed in a manual pulp remover and their mucilage was removed by natural fermentation in water for 24 $\mathrm{h}$, at room temperature. Then, seeds were washed and shade-dried on paper, and had their endocarp (parchment) removed. After oven-drying for $24 \mathrm{~h}$ at $105^{\circ} \mathrm{C}$, moisture content was evaluated in four replicates of 50 seeds and expressed in percentage (Brasil, 2009), with the seeds presenting $30 \%$ humidity.

\subsection{Anatomical and histochemical analyses of the germinating seeds}

Fifty seeds were placed on three sheets of germitest paper moistened with distilled water (2.5 times the weight of the paper) and kept in a chamber at $30^{\circ} \mathrm{C}$ for $0,3,6,12,24$, 30 and 45 days. These periods corresponded to events defined as prior to seed soaking ( 0 days), a short while after soaking (3 days), at half of the time for root protrusion (6 days), at the time expected for root protrusion (12 days), at double the time of root protrusion ( 24 days), at the recommended time to evaluate germination assays with coffee seeds (30 days), and when cotyledons were already open (45 days).

Twenty seeds samples were immediately fixed in neutral buffered formalin (NBF) (Kraus; Arduin, 1997) or in ferrous sulfate in formalin (FSF) (Johansen, 1940), for detection of phenolic compounds (control-prior to seed soaking).

A total of 10 seeds, from each of the 20 collected points (Figure 1, Table 1) and soaking periods, were used for anatomical analyses were each of the collected points contributed to repetitions (seeds) for the experiments conducted in a completely randomized design. Five seeds were sectioned and two glass slides for each histochemical test were mounted with five sections in each one. For each slide, five fields were photographed and analyzed for histochemistry and structural data collection.

The seeds were cross-sectioned at $30 \mu \mathrm{m}$ in a cryomicrotome (model LEICA CM 1850) and stained with the following reagents: Lugol (Johansen, 1940), for starch detection; Sudan Red (Brundett; Kendrick; Peterson, 1991), for lipids; NADI (David; Carde, 1964), for essential oils and oleoresins; Periodic Acid-Schiff stain (PAS) (O'Brien; McCully, 1981), for neutral polysaccharides; Coomassie Brilliant Blue (Fisher, 1968), for proteins; Acid Phloroglucin (Johansen, 1940), for structural phenolic compounds (lignins); Wagner's Reagent (Furr; Mahlverg, 1981), for alkaloids; Calcofluor White (Hughes; McCully, 1975), for $\beta-1,3$ and $\beta-1,4$ glucans; and Toluidine Blue (O’Brien; Feder; Mccully, 1964). Sections were mounted in histological glass slides and photographically documented in an Olympus AX 70 photomicroscope equipped with a U-Photo system.

\subsection{Enzyme assays by electrophoresis}

Seeds were collected following the procedure described above, for the histochemical tests, with the same germination periods and same conditions. Seed samples were immersed in liquid nitrogen and then stored at $-80^{\circ} \mathrm{C}$. Subsequently, crude enzyme extracts were obtained by maceration of seeds with $20 \mathrm{mg}$ polyvinylpyrrolidone (PVP) and liquid nitrogen in a closed-chamber ball mill (model MA 350), and then stored at $-80{ }^{\circ} \mathrm{C}$. Electrophoresis was run in a discontinuous system of polyacrylamide gels at $7.5 \%$ (resolving gel) and $4.5 \%$ (stacking gel). 

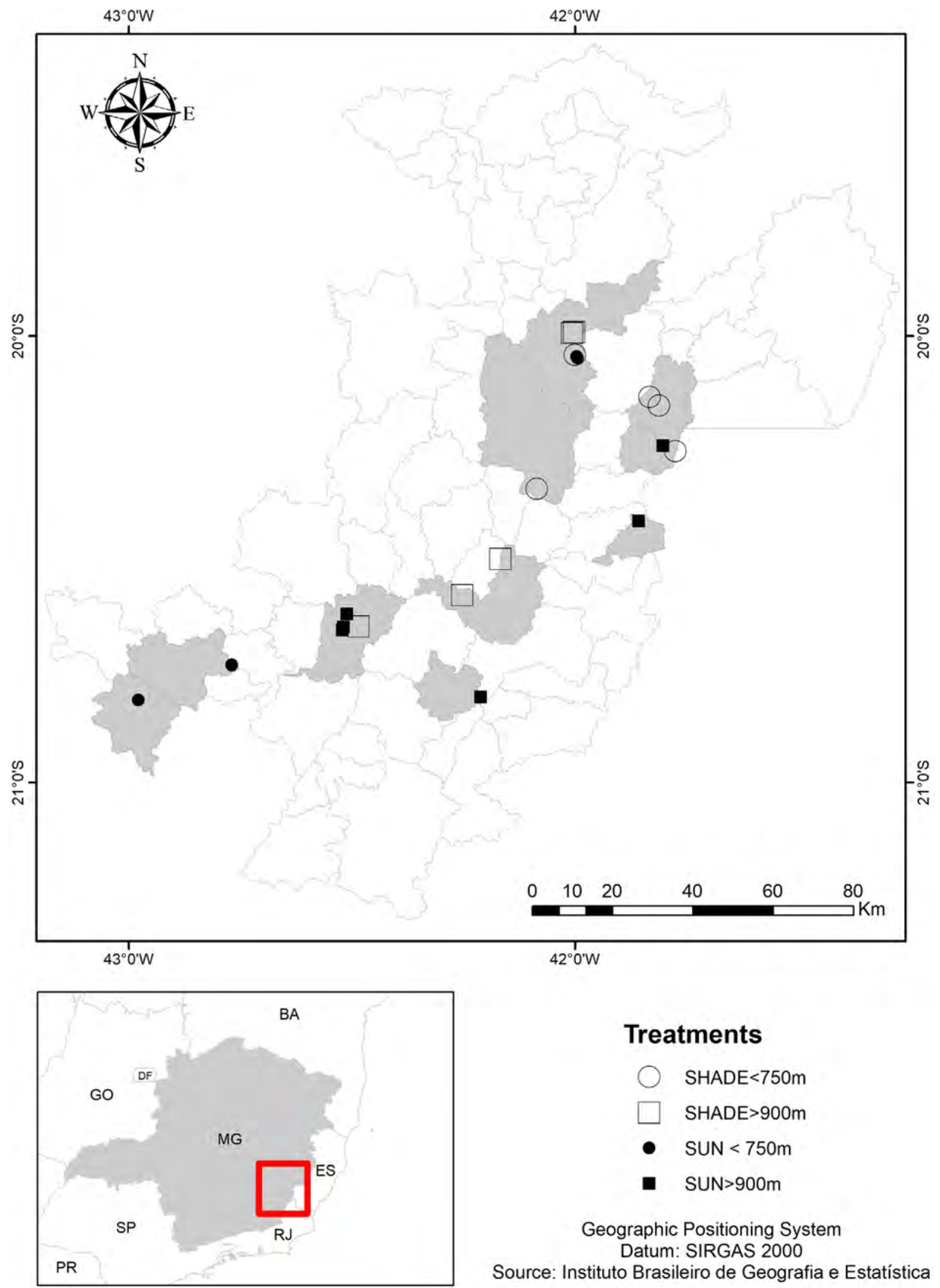

\section{Treatments}

SHADE $<750 m$

SHADE $>900 m$

- $\quad$ SUN $<750 m$

- $\quad \mathrm{UN}>900 \mathrm{~m}$

Geographic Positioning System

Datum: SIRGAS 2000

Source: Instituto Brasileiro de Geografia e Estatística

Figure 1: Collection sites of Coffea arabica L. cv 'Catuaí' seeds at different altitudes and mountainsides at the Matas de Minas (Southeast) region of Minas Gerais State, Southeastern Brazil. Plants were cultivated on sun-exposed (SUN) and shaded (SHADE) mountainsides, at altitudes lower than $750 \mathrm{~m}$ and higher than $900 \mathrm{~m}$. 
Table 1: Geographical coordinates of the Municipalities where the coffee seeds were sampled.

\begin{tabular}{cccc}
\hline Treatment & Latitude & Longitude & Municipality \\
\hline $\mathrm{NF}<750$ & -20.34252310 & -42.08546341 & Manhuaçu \\
$\mathrm{NF}<750$ & -20.04189156 & -42.00008660 & Simonésia \\
$\mathrm{NF}<750$ & -20.13668695 & -41.83273017 & Durandé \\
$\mathrm{NF}<750$ & -20.15576927 & -41.81127794 & Durandé \\
$\mathrm{NF}<750$ & -20.25810896 & -41.77498304 & Martins Soares \\
$\mathrm{NF}>900$ & -20.65102944 & -42.48491817 & Araponga \\
$\mathrm{NF}>900$ & -20.49908716 & -42.16682755 & Divino \\
$\mathrm{NF}>900$ & -20.58069035 & -42.25139994 & Divino \\
$\mathrm{NF}>900$ & -19.99260773 & -42.00579979 & Simonésia \\
$\mathrm{NF}>900$ & -19.99020179 & -42.00114272 & Simonésia \\
$\mathrm{SQ}<750$ & -20.04556971 & -41.99581577 & Simonésia \\
$\mathrm{SQ}<750$ & -20.04900687 & -41.99410091 & Simonésia \\
$\mathrm{SQ}<750$ & -20.81461000 & -42.97781000 & Paula Cândido \\
$\mathrm{SQ}<750$ & -20.73718000 & -42.76854000 & Viçosa \\
$\mathrm{SQ}>900$ & -20.65900876 & -42.52028586 & Araponga \\
$\mathrm{SQ}>900$ & -20.65235144 & -42.51827681 & Araponga \\
$\mathrm{SQ}>900$ & -20.62334963 & -42.51020637 & Araponga \\
$\mathrm{SQ}>900$ & -20.80820287 & -42.21049282 & São Francisco do Glória \\
$\mathrm{SQ}>900$ & -20.41483512 & -41.85648171 & Alto Caparaó \\
$\mathrm{SQ}>900$ & -20.24520418 & -41.80227938 & Durandé \\
\hline
\end{tabular}

The gel/electrode system used was Tris-glycine $\mathrm{pH}$ 8.9. A total $50 \mu \mathrm{L}$ of the supernatant was applied on the gel well and the analysis was run at $150 \mathrm{~V}$ for $5 \mathrm{~h}$. At the end of the run, gels were revealed for enzymes malate dehydrogenase (MDH EC.1.1.1.37) and superoxide dismutase (SOD - EC.1.15.1.1).

\section{RESULTS AND DISCUSSION}

Seeds had a moisture content of ca. $30 \%$ on a wet basis prior to soaking. The embryo was distinguished by showing a slightly whitish color, at the region near the seed top (Figure 2A). At 3 days of soaking, little difference in seed morphology is observed, while at 6 days the white color of the embryo can be easily discerned (Figure 2B and 2C). At 12 days of soaking, the radicle protrudes (Figure 2D). The endosperm of the coffee seed is formed by polyhedral living cells, being divided in two regions: a harder outermost region and a softer inner one close to the embryo (Walters; Arendt; Moroni, 2017). The availability of seed reserves may contribute to the irregular viability and slow, uneven germination of coffee seeds reported by Reis et al. (2010).

Reaching 24 days of soaking, the root system is well developed, and the taproot and lateral roots, all of them in formation, can already be seen, when endosperm integrity is still intact (Figure 2E). Following, at 30 days of soaking, the root system grows and the hypocotyl elongates; additionally, the seed softens, due to the breakdown of endosperm reserves (Figure 2F). By the $45^{\text {th }}$ day of soaking, cotyledon leaves are open and the seed residue is virtually devoid of reserves (Figure 2G). The altitude and mountainside had no apparent influence on germination of coffee seeds, since all treatment seed samples had similar development (Data not shown). Altitude and mountainside did not influence the reserve breakdown in coffee seeds based on the histological and histochemical observations.

The histochemical analyses revealed that, independently the period of soaking, the results were negative for Acid Phloroglucin and Lugol, the latter evidencing the absence of starch storage in the coffee seeds. We identified the presence phenolic compounds, lipids, oleoresin, proteins, alkaloids, and cell wall structural carbohydrates (Figure 3). Histochemical positive results are compared to blanc treatment (control nontreated samples) (Figure 3A).

Structural polysaccharides, mainly cellulose, is evidenced in endosperm cell walls (Figure 3B), which are evidenced in cell walls as reacting positively to PAS (Figure 3C). Additionally, we observed the presence of $\beta-1,3$ and $\beta-1,4$ glucans (hemicellulose) by the reaction of the embryo cell walls with Calcofluor White (Figure 3D). We also observed that endosperm cells are thick-walled and irregularly shaped (Figure 3A, 3B and 3C), while embryo cells are isodiametric (Figure 3D). Variation in cell wall thickness was observed (Figure 3A, 3B and 3C).

The walls of endosperm cells are mainly constituted by structural polysaccharides, as pectin and hemicellulose, as observed in the histochemical tests in our results. Endosperm cells also have proteins and lipids in their cytoplasm (Waters; Arendt; Moroni, 2016; Verhertbruggen et al., 2019; Roustan et al., 2020), as well as oleoresin, phenolic compounds and alkaloids.

The toluidine blue staining highlight the differences of cell wall thickness of endosperm cells throughtout coffee seed germination. Blue staining evidences the presence of cellulose. Hemicelluloses have both structural and storage roles in the analyzed seeds, and is a typical feature of the coffee bean, which has part of its reserve material stored in the walls of endosperm cells.. Hemicelluloses can account for ca. $40-60 \%$ of the dry weight of seeds and consist mainly in galactomannans and arabinogalacturonnan proteins (Clifford, 1985; Sousa et al., 2017).

The tests for lipids (Sudan Red) and essential oils and oleoresins (NADI) exhibited positive results. In the endosperm cells, part of this lipid material reacted positively to the test for detection of oleoresin (Figure 3E), whereas oil bodies are also observed, which were overall well distributed across the cells (Figure 3F). The reaction for phenolic compounds (Ferrous sulfate in formalin) (Figure 3G), alkaloids (Wagner's Reagent) (Figure 3H) and total proteins (Comassie Blue) (Figure 3I), were also positive. This highlight the presence of these groups of compounds in endosperm cells. Reserve breakdown in 
coffee seeds showed no variation among the studied seed development conditions (altitudes and mountainsides) based on the histochemical and histological observations. This behavior was observed in the pattern of histochemical tests and analysis performed with great representativeness. We used 50 seeds in each test, of these 20 were for histochemical analysis. With the production of 5 slides per sample and generation of 10 images per slide.
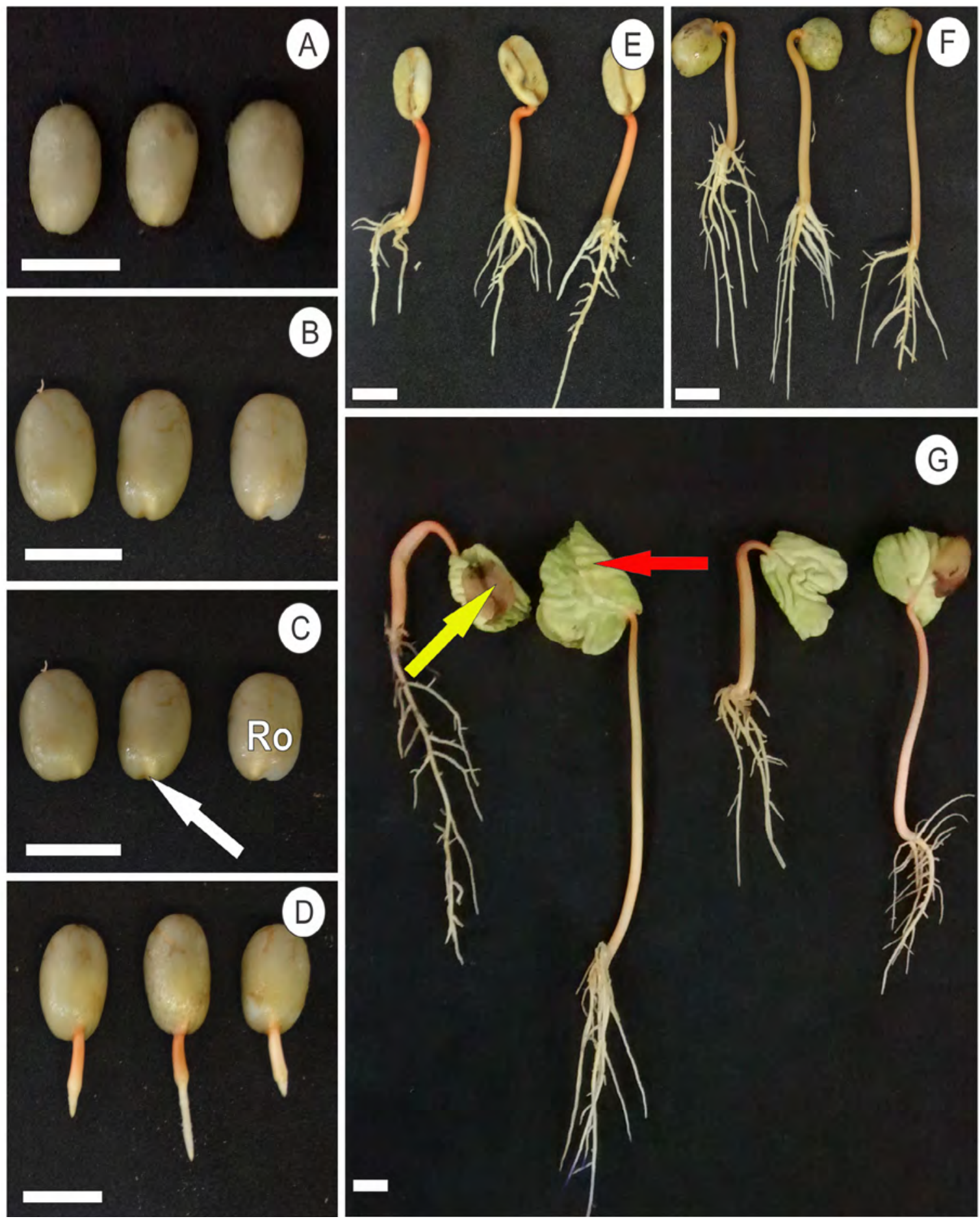

Figure 2: Germination of Coffea arabica L. cv. 'Catuaí' seeds. (A) Seeds before soaking; (B) seeds 3 days of soaking; (C) seeds 6 days after soaking, a white spot corresponds to the expanding root; (D) seeds 12 days of soaking, root protrusion; (E) seeds 24 days of soaking, details of the developing seedling; ( $F$ ) seeds 30 days of soaking, details of the developing seedling; and ( $G$ ) seeds 45 days of soaking, remaining endosperm tissues and expanding cotyledon leaves. White arrow (Ro) - expanding root, yellow arrow - endosperm remains, red arrow - expanding cotyledon leaves. Bars $=1 \mathrm{~cm}$. 

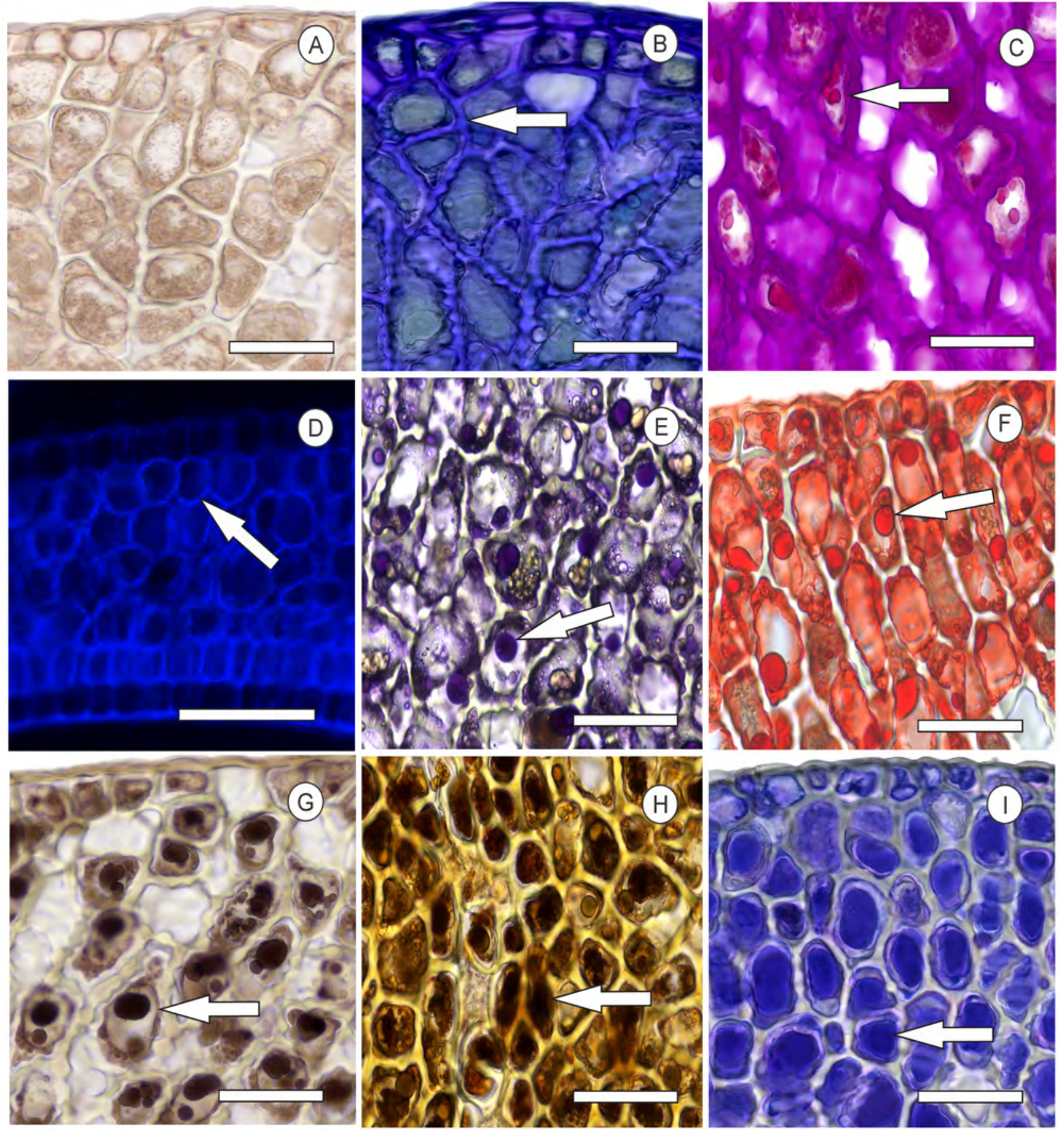

Figure 3: Histochemical assesments. Detail of the endosperm cross sections of Coffea arabica L. cv 'Catuaí' seeds. (A) control; (B) Toluidine Blue, (C) PAS, (D) Calcofluor White, (E) NADI reagent, (F) Sudan Red, (G) Ferrous sulfate in formalin, (H) Wagner's Reagent, and (I) Coomassie Blue. All assesments were performed on endosperm samples, except for D, which was on embryo sample. White arrows evidence positive reaction for each histochemical test: B - cellulose (metachromatic dye), C- Neutral polysaccharides, D - $\beta-1,3$ and $\beta-1,4$ glucans, E - Oleoresins, F - Total lipids, G - Total phenolics, H - Alkaloids and I - Total proteins. Bars $=100 \mu \mathrm{m}$.

Compared to control treatment ( 0 days of soaking) (Figure 4A), little difference in reserve breakdown was observed after 3 and 6 days of soaking. However, at 12 days of soaking (Figures 4B and 4C), the consumption of reserve material of cell walls and cytoplasm begun, especially from the region closest to the embryo (Figures $4 \mathrm{~B}$ and $4 \mathrm{C}$ ). This mobilization was more evident at 30 days of soaking, when higher reserve consumption took place not only in the endosperm region closest to the embryo but also in the endosperm mid region (Figures 4D and 4E). 

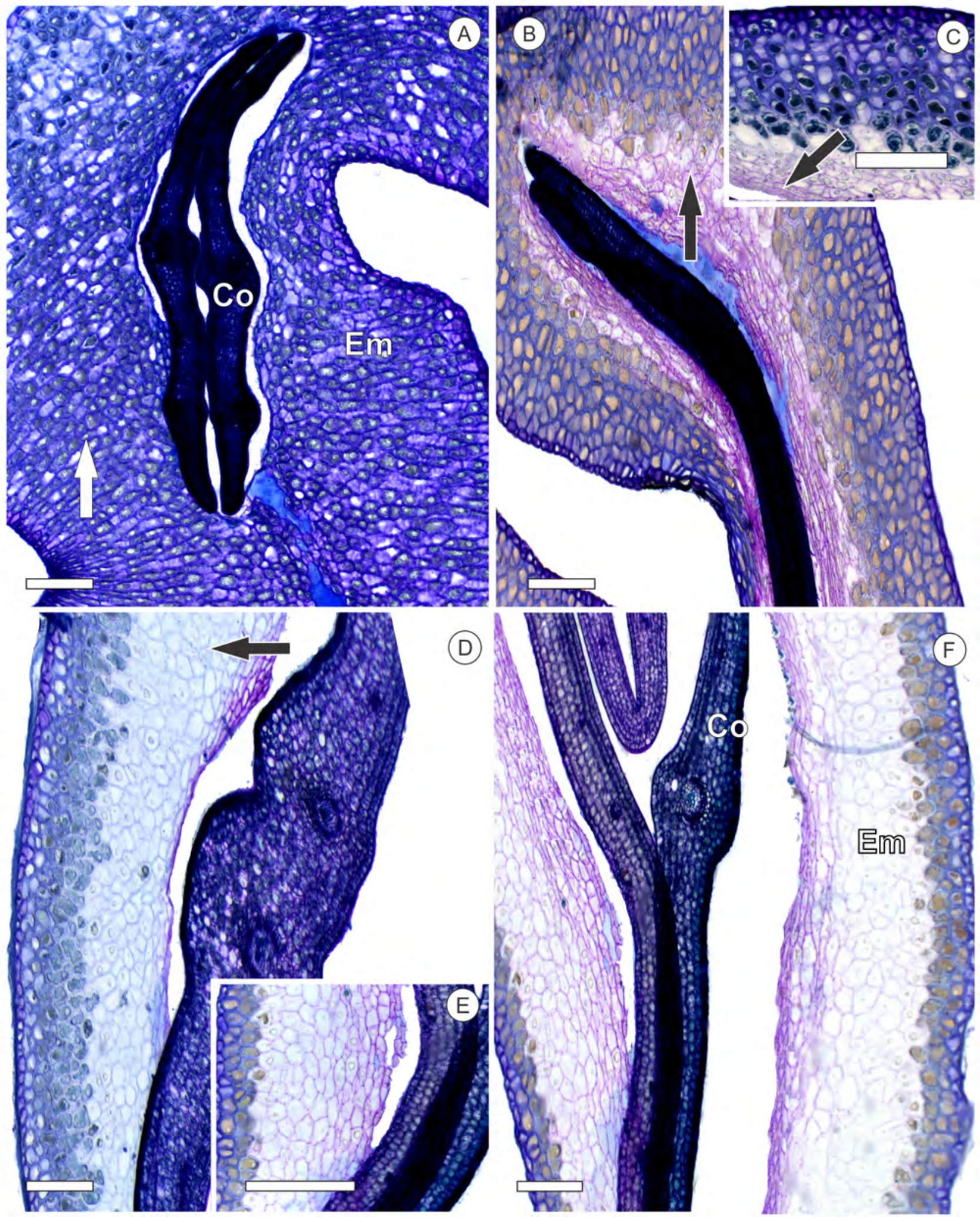

Figure 4: Cross sections of germinating Coffea arabica L. cv 'Catuaí' seeds. Details of the embryo and the endosperm stained with Toluidine Blue. (A) 0 days of soaking; (B and C) 12 of after soaking, observe the endosperm cell wall thinning and the collapse of cells near the embryo; ( $D$ and $E$ ) 30 days of soaking, cell expansion and ongoing expansion of the cotyledon leaf; and ( $F$ ) 45 days of soaking, progressive on endosperm cell wall thinning. Co, cotyledon; en, endosperm. White arrow, Buid up endosperm cell walls; black arrows, collapsed and weakened endosperm cell walls. Bars $=300 \mu \mathrm{m}$. 
At 45 days of soaking, reserve material was no longer observed in the cytoplasm and cell walls were practically absent of thickening (Figure 4F). This is evidenced by the lower wall thickness of endosperm cells and cell collapse of the endosperm cells near the embryo. It is highlighted that the reserve mobilization occurred from the inside out in the endosperm, which was showed by the higher degradation degree of the walls of cells from the regions closest to the embryo (Figure 4A to 4F).

In view of the change in the staining of endosperm cells before soaking (Figure 4A), we observed a dynamic alteration of the endosperm cell wall thickness due to germination (Figures $4 \mathrm{~B}$ to $4 \mathrm{~F}$ ). Concomitantly to the breakdown of cytoplasmic reserves, the interlinked chemical and structural alteration of cell walls reflected and contributed to the occurrence of degradation of structural carbohydrates, resulting in cell collapse (Figure 4B, 4D and 4F).

The breakdown of reserve compounds in the cytoplasm can be clearly observed (Figure 5) such as for lipids (Figure 5A to 5G), proteins (Figures $5 \mathrm{H}$ to $5 \mathrm{~L}$ ) and essential oils/oleoresins (Figures $5 \mathrm{M}$ to $5 \mathrm{Q}$ ). The consumption of these reserves followed the same trends observed to cell wall reserve compounds (Figure 4).

We detected an evident mobilization of lipids (Figure 5C), proteins (Figure $5 \mathrm{~J}$ ) and essential oils (Figure $5 \mathrm{~N}$ ) from 12 days, and more intensely at 30 days of soaking (Figures 5D, $5 \mathrm{~K}$ and $5 \mathrm{O}$ ). At 45 days of soaking, we observed little positive reaction for proteins and virtually no reserve of lipids (Figure 5F) or oleoresin (Figure 5Q) in the endosperm.

There are clear differences on the chemical composition of the cell walls of the endosperm cells during seed germination (Figures 4 and 5). Nevertheless, the persistence of lipid (Figure $5 \mathrm{~F}$ ), protein (Figures $5 \mathrm{~K}$ and $5 \mathrm{~L}$ ) and oleo resin (Figure 5Q) components are noticed at the outer endosperm cell layers, particularly, at the cuticle of the epidermal layer, from 30 days of soaking and on. At this same period of soaking, the same substances are not observed in the inner cell layers in contact with the embryo. Protein reserves were observed to be hydrolyzed (Figures $5 \mathrm{H}$ to $5 \mathrm{~L}$ ), what was associated with sustaining embryo growth during germination.

Coffee seed cells have a large amount of storage material in the cytoplasm and structural carbohydrates in the cell wall, as well as of oleoresin alkaloids in both cytoplasm and cell walls (Goulart et al., 2007; Zain; Shori; Baba, 2017). Storage compounds such as lipids, proteins and hemicellulose, that although less usually described, are mobilized during germination. Such mobilization starts in the region near the embryo, which facilitates the suppling of energy for embryo growth.

Seed germination starts with water absorption and ends with radicle protrusion through the tissues that surround the embryo (Bewley et al., 2013; Lechowska et al., 2019). Seed soaking enables the resumption of the reduced cell metabolism, after a period of metabolic quiescence that follows seed harvesting and drying (Ibrahim et al., 2019). As for radicle protrusion, it results from the concurrent interaction between the embryo growth potential, provided by cell elongation and division, and the limiting mechanical force of the tissues in the micropyle region (Zhang; Chen; Xu, 2014; Carrera-Castaño et al., 2020). The observed cell wall breakdown is thought to contribute with carbon skeletons as well as an environment less amenable to physical damage by occasion of the root protrusion and cotyledon expansion. Carrera-Castaño et al. (2020) and Walters Arendt and Moroni (2017) reported the weakening of the endosperm during the embryo development.

The germination process results from the concurrent interaction between the embryo growth potential and the limiting mechanical force of the tissues surrounding the embryo (Barros-Galvão; Vaistij; Graham, 2019; Zhang; Chen; $\mathrm{Xu}, 2014)$. Two stages of endosperm weakening have been reported to occur during germination of coffee seeds (Da Silva et al., 2019), in which case the endosperm constitutes the mechanical force of tissues surrounding the embryo. During the first stage, the water absorbed by the walls of endosperm cells is gradually transmitted to the embryo, which increases its pressure potential (Almeida et al., 2018), thereby characterizing the embryo growth potential. Gradually, the endosperm structure is weakened and the walls of its cells are degraded, which enables the nurturing of the growing embryo.

During the second stage, the embryo pressure potential is released and a protuberance is formed on the region where the radicle will protrude (Walters; Arendt; Moroni, 2017). This weakening of the endosperm region creates empty spaces and reduces cell integrity in the region, thus enabling radicle protrusion. At the same time, mobilization of compounds both in the cytoplasm and cell walls supply energy for the division and elongation of embryo cells. In coffee seeds, hydration of cells that compose the lateral endosperm occurs more slowly than that of cells that compose the micropylar endosperm, after the first five days of hydration (Da Silva et al., 2008).

According to Da Rosa et al. (2010), sensu stricto germination of coffee seeds takes place after seven days of soaking. This explains the higher reserve mobilization observed after radicle protrusion at 10-12 days of soaking. Little mobilization of reserve compounds was observed at 6 days of soaking, while at 12 days the mobilization was more evident at the region closest to the embryo (Figure 4).

Reserve mobilization after that period may be associated with radicle protrusion, which demand higher energy supply for plantlet development. There was a higher reserve mobilization at 24 and 30 days of soaking and at 45 days reserves were virtually absent from the endosperm (Figure 4 and 5). Da Rosa et al. (2010) reported a prominent development of the taproot as well as of lateral roots at 24 and 30 days, and at 45 days cotyledon leaves were expanded. The same patterns were observed for the plantlets in the present work (Figure 2). 

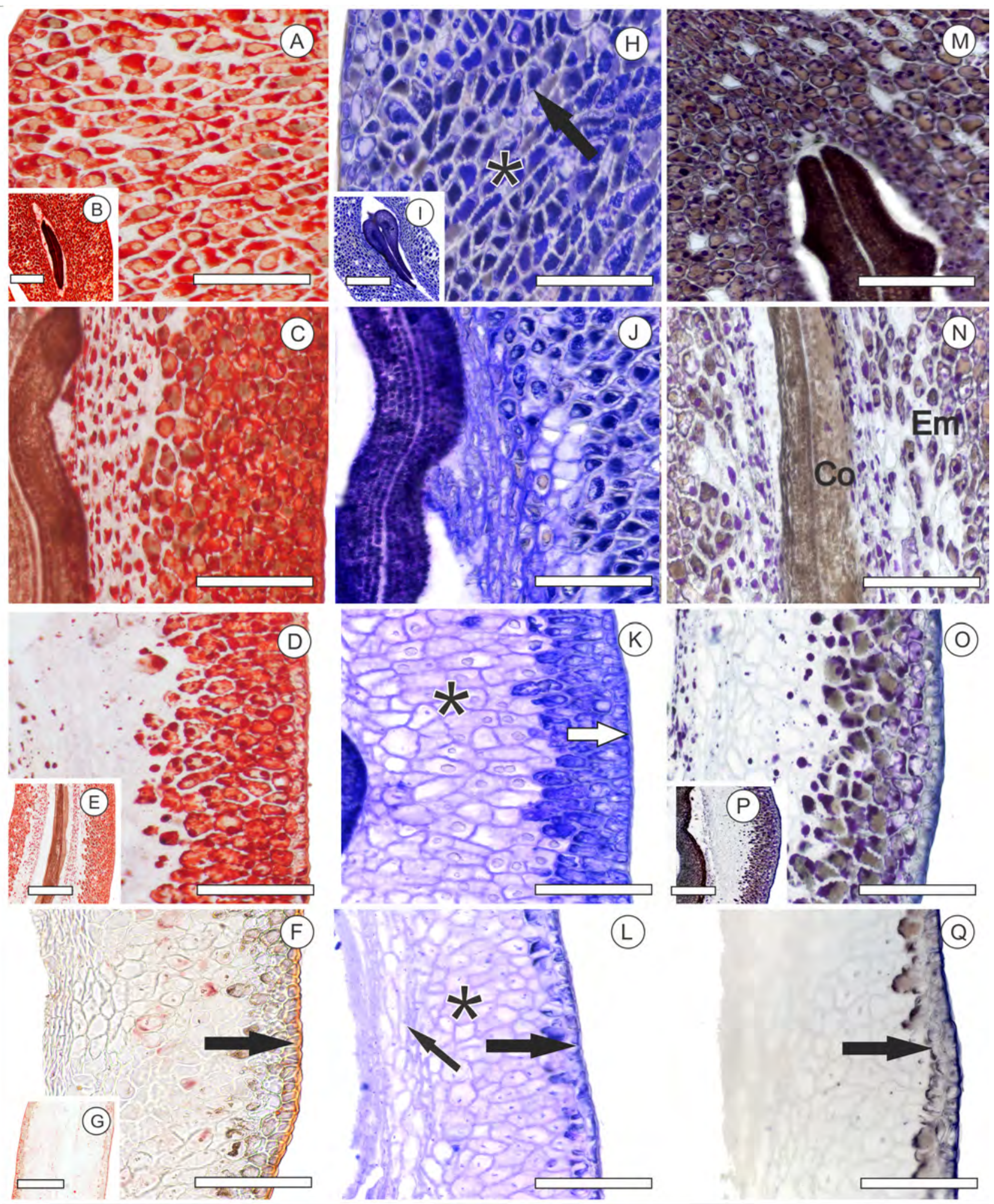

Figure 5: Histochemical assessments of cross sections of germinating Coffea arabica L. cv 'Catuaí' seeds at different periods of soaking, evidencing the ongoing of reserve consumption during seed germination. $A, B, H, I$ and $M-0$ days of soaking; $C$, $J$ and $\mathrm{N}$ - 12 days of soaking; D, E, K, O and P - 30 days of soaking; and F, G, L and Q - 45 days of soaking. Sudan red (Lipids) (A-G); Comassie Blue (proteins) $(\mathrm{H}-\mathrm{L})$; Nadi reagent (oleoresin) $(\mathrm{M}-\mathrm{Q})$. Bars: larger micrographs $=300 \mu \mathrm{m}$; detail micrographs $=600$ $\mu \mathrm{m}$. Co, cotyledon; En, endosperm. White asterisk - non-collapsed endosperm cells; black asterisk - endosperm cells depleted of protein reserves; black arrow - protein reserves in endosperm cells; black arrowhead - collapsed endosperm cells; long white arrow - cuticle at the outer epidermal cells. 
Cytoplasmic reserves, such as proteins and lipids, are mobilized more rapidly than cell-wall compounds. This was evidenced by the maintenance of seed integrity, especially at the seed coat region, until nearly the end of our analyses (Figure 2; Figure 5D and 5K). More accessible reserves, like proteins, are necessary for the first germination events, as they provide carbon skeletons to form carbohydrates of high molecular weight, amino acids, and enzymes (Bewley et al., 2013).

The consumption of the coffee endosperm cell wall reserves, approximately at the $12^{\text {th }}$ day after soaking, provide carbon skeletons either provide a suitable physical environment for the developing embryo. As the cell reserves are consumed at the endosperm near the embryo, the void space of the cell lumen and chemical alteration of the cell wall based on the histochemical tests are observed. Associated with the endosperm physiological nourishment role, these events are possible causes and concomitant with the inner endosperm cell collapse surrounding the Coffea embryo, but not on the outer cell layers, which provide suitable physical space for its development.

The altitude and mountainside had no influence on the activity of the evaluated enzymes whereas it did fluctuate during coffee seed germination. The malate dehydrogenase $(\mathrm{MDH})$ profile showed significant differences in enzyme expression along seed germination. The higher expression of $\mathrm{MDH}$ activity in control samples and in samples at 12 days of soaking occurred in all evaluated treatments (Figure 6A). Little or no expression of this enzyme was observed from 30 days of soaking (Figure 6A).

The inverse behavior was detected for superoxide dismutase (SOD), which showed higher expression at the more advanced imbibition times of 30 and 45 days. At 24 days of soaking, there was little enzyme activity expression, while at 0 and 12 days such expression was virtually non-existent (Figure 6B).

Water supply enables rapid recovery of cell metabolism during soaking, and may even create an inadequate redox state for seed survival (Kalemba Ratajczak, 2018), due to the increase in concentration of reactive oxygen species (ROS), whose excess may damage cell metabolism. However, recent research has suggested that these molecules are signals involved in the activation of processes that promote germination (Meng et al., 2017; Anand et al., 2019). This fact in turn suggests that increased ROS concentration at early imbibition may be used to facilitate germination, as it accelerates cell wall degradation and the occurrence of programmed cell death, both of which are fundamental processes that regulate root protrusion, promoting the loosening of tissues in the micropylar region (Zhang; Chen; Xu, 2014; Barros-Galvão; Vaistij; Graham, 2019).

Ulterior alterations in redox balance promote an increase in the activity of oxidative stress enzymes, which allows the cells to recover balance. Thereby, as the redox balance is reestablished in the cell, respiratory metabolism is maintained active and the breakdown of reserves is ensured, as is the provision of energy to embryo and plantlet growth. The change in redox state also causes thioredoxin to reduce the disulfide bonds of proteins. Such modification in protein structure contributes to the degradation of reserve compounds (Alkhalfioui; Renard; Vensel, 2007; Calderón; Sevilla; Jiménez, 2018; Hãgglund et al., 2019; Montrichard et al., 2019), thus facilitating their mobilization to supply seed germination and plantlet growth, as it enables the degradation of starch and proteins by promoting susceptibility to amylases and proteases (Alkhalfioui; Renard; Vensel, 2007).

The enzyme malate dehydrogenase (MDH), from the TCA cycle, showed increased activity during early germination, especially until the first 12 days (Figure 6A). In that period, reserve material was mobilized (Figure 3, 4 and 5). MDH participates not only in the TCA cycle, but also in gluconeogenesis (Alkhalfioui Renard; Vensel, 2007). This justifies the increased activity of the enzyme during early soaking, when, considering the seed moisture content of $30 \%$, there are still conditions for metabolic activity in seed tissues.

The same behavior is expected for other enzymes related to the breakdown of reserves at early soaking, which may have contributed to a higher reserve mobilization from 12 days, since radicle protrusion was observed at between 10 and 12 days of soaking. Most energy in the seed is consumed during post-germination events, supplying early development before plantlets become autotrophic (Bicalho et al., 2016). This observation is in accordance with the kinetics of reserve compounds observed in coffee seeds, in which reserve mobilization occurs after sensu stricto germination, when compounds, including cell-wall ones, are degraded, thereby enabling the supplying of carbohydrates for developing tissues (Bewley et al., 2013).

Gradual decrease in $\mathrm{MDH}$ activity may result in decreased respiration and reduced metabolic activity, and may be associated with seed ageing (Xin et al., 2014; Yin et al., 2016). In such case, increased MDH activity until 12 days of imbibition indicates high respiratory rates due to reserve breakdown, while decreased MDH activity after 24 days indicates a lower need for the activity of the enzyme, i.e., a less strong relationship between $\mathrm{MDH}$ and reserve breakdown. This suggests the participation of other enzymes in the process, such as the hydrolases endo- $\beta$-mannanase, $\alpha$-galactosidases, polygalacturonases and pectin methylesterase, all of which contribute to the weakening of micropylar endosperm (Zhang; Chen; Xu, 2014; Bicalho et al., 2016). These enzymes also act in the weakening of the cell wall by mobilization of reserve material stored in the walls, thereby ultimately enabling and/ or contributing to radicle protrusion (Zhang; Chen; Xu, 2014; Borges et al., 2015). 


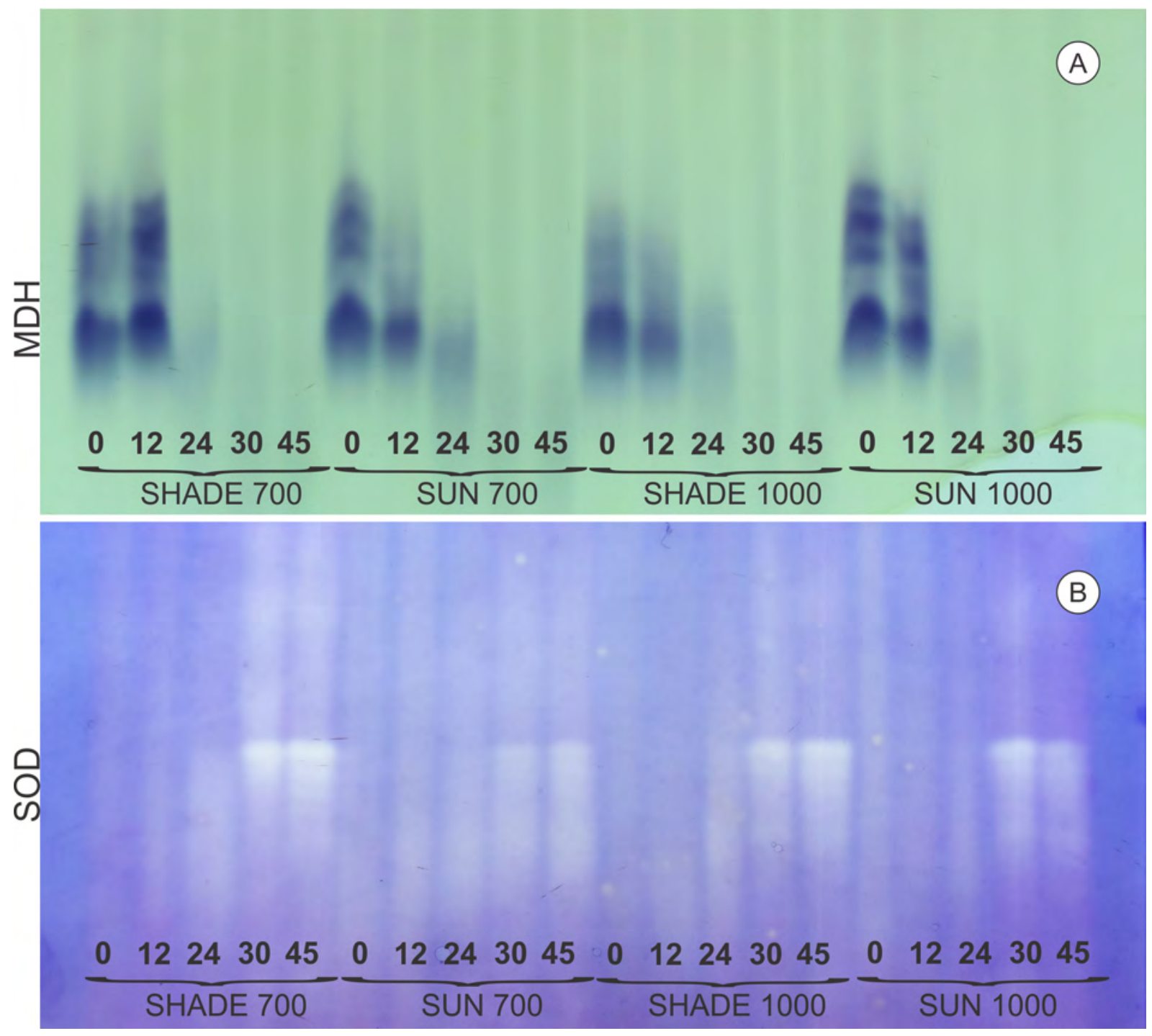

Figure 6: Electrophoretic expression of malate dehydrogenase (MDH) (A) and superoxide dismutase (SOD) (B) enzymes in germinating seeds of Coffea arabica L. cv 'Catuaí' at 0, 12, 24, 30, and 45 days of soaking. Seeds were harvested from plants that were cultivated on sun-exposed (SUN) and shaded (SHADE) mountainsides, at altitudes lower than $750 \mathrm{~m}$ and higher than $900 \mathrm{~m}$.

The higher expression of SOD bands at 30 and 45 days of imbibition (Figure 6B) can be attributed both to increased mitochondrial activity, which was resumed during soaking, and to reserve exhaustion. Reserve exhaustion renders metabolic alterations necessary for plantlets to become autotrophic, since during germination most of the ROS is formed due to the resumption of respiratory metabolism, which has its major source in mitochondrial activity (Gomes; Garcia, 2013; Yin et al., 2016). This occurs because the electrons transported by the electron transport chain have sufficient free energy to directly reduce $\mathrm{O}_{2}$, especially at complexes I and II. As these complexes are the main sources of substrate for SOD, an increase in their activity is required to dismutate $\mathrm{O}_{2}^{-}$to $\mathrm{H}_{2} \mathrm{O}_{2}$ (Majumdar; Kumarkara, 2019). Such increased SOD activity may also be related to the stress caused by the imbibition period. The moisture and temperature conditions to which seeds are subjected during imbibition allow for maintaining metabolism at high levels and propitiate the proliferation of microorganisms that increase cellular stress in plantlets.

\section{CONCLUSIONS}

The storage components present in coffee seeds is intensely consumed, starting from the endosperm, the middle and outer cell layers towards the embryo.

The mobilization is more intense after protrusion of the radicle, about 12 days of immersion, when the MDH is more active.

Protein and lipids are consumed first, followed by the use of structural cell wall carbohydrates which result in the collapse of endosperm cells near the embryo. 


\section{ACKNOWLEDGEMENTS}

This work was supported by Fundação de Amparo à Pesquisa de Minas Gerais (FAPEMIG), Empresa de Pesquisa Agropecuária de Minas Gerais (EPAMIG), Consórcio Pesquisa Café, Empresa Brasileira de Pesquisa Agropecuária (EMBRAPA), and the Laboratories of Plant Anatomy, of Mycorrhizae, and of Seeds, at Federal University of Viçosa. We are also indebted with Suzano Papel e Celulose for supporting other ongoing projects in our Laboratory and IC grants for undergrad students that, in addition to their tasks, contributed to this research on coffee seed anatomy.

\section{REFERENCES}

ALKHALFIOUI, F.; RENARD, M.; VENSEL, W. H. Thioredoxin-linked proteins are reduced during germination of Medicago truncatula seeds. Plant Physiology, 144:1559-1579, 2007.

ALMEIDA, J. A. S. D. et al. Water stress in germination, growth and development of coffee cultivars. Journal of Seed Science, 40(1):82-89, 2018.

ANAND, A. et al. Hydrogen peroxide signaling integrates with phytohormones during the germination of magnetoprimed tomato seeds. Scientific Reports, 9(1):1$11,2019$.

ARCILA-PULGARÍN, J. et al. Application of the extended $\mathrm{BBCH}$ scale for the description of the growth stages of coffee (Coffea spp.). Annals of Applied Biology, 141(1):19-27, 2002.

ASSIS, J. G. R. et al. Expression of Enzymes During the Germination of Seeds in Endangered Cerrado Species. Journal of Agricultural Science, 11(6):111,2019 .

BARROS-GALVÃO, T.; VAISTIJ, F. E.; GRAHAM, I. A. Control of seed coat rupture by ABA-INSENSITIVE 5 in Arabidopsis thaliana. Seed Science Research, 29(2):143$148,2019$.

BEWLEY, J. D. et al. Seeds: Physiology of development, germination and dormancy. 3rd ed., New York Springer, 2013. 392p.

BICALHO, E. M. et al. Enzyme activity and reserve mobilization during Macaw palm (Acrocomia aculeata) seed germination. Acta Botanica Brasilica, 30(3):438444, 2016.

BORGES, E. E. L. et al. Alterações fisiológicas e atividade enzimática em sementes armazenadas de Melanoxylon brauna Schott. Cerne, 21(1):75-81, 2015.
BRASIL, Ministério da Agricultura e da Reforma Agrária. Regras para análise de sementes. Brasília, 2009. 398p.

BRUNDRETT, M. C.; KENDRICK, B.; PETERSON, C. A. Efficient lipid staining in plant material with sudan red 7B or fluoral yellow 088 in polyethylene glycol-glycerol. Biotechnic \& Histochemistry, 66(3):111-116, 1991.

CALDERÓN, A.; SEVILLA, F.; JIMÉNEZ, A. Redox protein thioredoxins: function under salinity, drought and extreme temperature conditions. In: GUPTA, D. K.; PALMA, J. M.; CORPAS, F. J. (Eds.). Antioxidants and Antioxidant Enzymes in Higher Plants. Springer, Cham, p.123-162, 2018.

CARRERA-CASTAÑO, G. et al. An Updated Overview on the Regulation of Seed Germination. Plants, 9(6):703, 2020.

CARVALHO, A. M. C.; GUIMARÃES, R. M.; SILVA, T. T. A. Condicionamento fisiológico em matriz sólida de sementes de café (Coffea arabica L.) com e sem pergaminho. Revista Brasileira de Sementes, 34(1):094-098, 2012.

CLIFFORD, M. N. Chlorogenic Acids. In: CLARKE R. J.; MACRAE, R. Coffee, Vol 1. Springer, Dordrecht, p.153-202, 1985.

DA ROSA, S. D. V. F. et al. Staging coffee seedling growth: A rationale for shortening the coffee seed germination test. Seed Science and Technology, 38(2):421-431, 2010.

DA SILVA, E. A. A. et al. Exogenous gibberellins inhibit coffee (Coffea arabica cv. Rubi) seed germination and cause cell death in the embryo. Journal of Experimental Botany, 56(413):1029-1038, 2005.

DA SILVA, E. A. A. et al. ABA Inhibits Embryo Cell Expansion and Early Cell Division Events During Coffee (Coffea arabica 'Rubi') Seed Germination. Annals of Botany, 102(3):425-433, 2008.

DA SILVA, E. A. A. D. et al. Gene expression during the germination of coffee seed. Journal of Seed Science, 41(2):168-179, 2019.

DAVID, R.; CARDE, J. P. Coloration différentielle dês inclusions lipidique et terpeniques dês pseudophylles du Pin maritime au moyen du reactif Nadi. Comptes Rendus Hebdomadaires dês Séances de l'Academie dês Sciences Paris, 258:1338-1340, 1964.

DEDECCA, D. M. Anatomia e desenvolvimento ontogenético de Coffea arabica L. var. Typica Cramer. Bragantia, 16:315-355, 1957.

EIRA, M. T. et al. Coffee seed physiology. Brazilian Journal of Plant Physiology, 18(1):149-163, 2006. 
FARIAS, E. T. et al. Expression studies in the embryo and in the micropylar endosperm of germinating coffee (Coffea arabica cv. Rubi) seeds. Plant Growth Regulation, 75(2):575-581, 2015.

FERREIRA, V. F. et al. Endo- $\beta$-mannanase enzyme activity in the structures of Coffea arabica L. seeds under different types of processing and drying. Ciência Rural, 48(12):e20170839, 2018.

FISHER, D. B. Protein staining of ribboned epon sections for light microscopy. Histochemie, 16(1):92-96, 1968.

FURR, M.; MAHLBERG, G. Histochemical analyses of laticifers and glandular trichomes in Cannabis sativa. Journal of Natural Products, 44(2):153-159, 1981.

GOMES, M. P.; GARCIA, Q. S. Reactive oxygen species and seed germination. Biology, 68(3):351-357, 2013.

GOULART, P. F. P. et al. Aspectos histoquímicos e morfológicos de grãos de café de diferentes qualidades. Ciência Rural, 37(3):662-666, 2007.

HÄGGLUND, P. et al. Seed thioredoxin h. Biochimica et Biophysica Acta (BBA). Proteins and Proteomics, 1864(8):974-982, 2016.

HE, Y. et al. Glyoxylate cycle and reactive oxygen species metabolism are involved in the improvement of seed vigor in watermelon by exogenous GA3. Scientia Horticulturae, 247:184-194, 2019.

HEBER, U. Metabolite exchange between chloroplasts and cytoplasm. Annual Review of Plant Physiology, 25(1):393-421, 1974.

HUGHES, J.; MCCULLY, M. E. The use of an optical brightener in the study of plant structure. Stain Technology, 50(5):1037-1041, 1975.

IBRAHIM, E. A. A. Fundamental Processes Involved in Seed Priming. In: HASANUZZAMAN, M.; FOTOPOULOS, V. Priming and Pretreatment of Seeds and Seedlings. Springer, Singapore, p.63-115, 2019.

JIA, M. X. et al. CAT and MDH improve the germination and alleviate the oxidative stress of cryopreserved Paeonia and Magnolia pollen. Acta Physiologiae Plantarum, 40(2):37, 2018.

JOHANSEN, D. A. Plant microtechnique. New York, McGraw-Hill, 1940. 523p.

KALEMBA, E. M.; RATAJCZAK, E. The effect of a doubled glutathione level on parameters affecting the germinability of recalcitrant Acer saccharinum seeds during drying. Journal of Plant Physiology, 223:72-83, 2018 .

KRAUS, J. E.; ARDUIN, M. Manual básico de métodos em morfologia vegetal. Rio de Janeiro EDUR, 1997. 198p.

LECHOWSKA, K. et al. New insight on water status in germinating Brassica napus seeds in relation to primingimproved germination. International Journal of Molecular Sciences, 20(3):540, 2019.

MAJUMDAR, A.; KAR, R. K. Orchestration of Cu-Zn SOD and class III peroxidase with upstream interplay between NADPH oxidase and PM H+-ATPase mediates root growth in Vigna radiata (L.) Wilczek. Journal of Plant Physiology, 232:248-256, 2019.

MENG, Y. et al. Karrikins: Regulators involved in phytohormone signaling networks during seed germination and seedling development. Frontiers in Plant Science, 7:2021, 2017.

MONTRICHARD, F. et al. Role of thioredoxins and NADPthioredoxin reductases in legume seeds and seedlings. In: BRUJIN, F. (Eds.). The Model Legume Medicago truncatula, Chapter 3.1.5, p.80-91, 2019.

O'BRIEN, T. P.; MCCULLY, M. E. The study of plant structure: Principles and selected methods. Melbourne, Termarcarphi PTY. LTD, 1981. 357p.

O'BRIEN, T.; FEDER, N.; MCCULLY, M. E. Polychromatic staining of plant cell walls by toluidine blue $\mathrm{O}$.

Protoplasma, 59:367-373, 1964.

OTEGUI, M. S. et al. The Proteolytic Processing of Seed Storage Proteins in Arabidopsis Embryo Cells Starts in the Multivesicular Bodies. The Plant Cell, 18(10):25672581, 2006.

REIS, L. P.; SOUZA, G. A. D.; BRITO, D. S. Relationships between substrate and the mobilization of reserve with temperature during seed germination of Ormosia coarctata Jack. Journal of Seed Science, 42:e202042017, 2020.

REIS, P. R. et al. Manejo integrado das pragas do cafeeiro. In: REIS, P. R.; CUNHA, R. L. Café arábica: Do plantio à colheita. EPAMIG Sul de Minas, Lavras, p.573-688, 2010.

ROUSTAN, V. et al. Protein sorting into protein bodies during barley endosperm development is putatively regulated by cytoskeleton members, MVBs and the HvSNF7s. Scientific Reports, 10(1):1-19, 2020.

SELMAR, D. et al. Germination of coffee seeds and its significance for coffee quality. Plant Biology, 8(2):260264, 2006. 
SOUSA, F. D. et al. Physicochemical properties of edible seed hemicelluloses. Open Access Library Journal, 4(6):1-14, 2017.

SOUZA, G. A. et al. Morpho-anatomical, physiological and biochemical changes in rubber tree seeds. Anais da Academia Brasileira de Ciências, 90(2):1625-1641, 2018.

TUNES, L. M. D. et al. Influência dos diferentes períodos de colheita na expressão de isoenzimas em sementes de cevada. Revista Ceres, 58(2):178-184, 2011.

VERHERTBRUGGEN, Y. et al. Challenging the putative structure of mannan in wheat (Triticum aestivum) endosperm. Carbohydrate Polymers, 224:e115063, 2019.

WALTERS, D. M.; ARENDT, E. K.; MORONI, A. V. Overview on the mechanisms of coffee germination and fermentation and their significance for coffee and coffee beverage quality. Critical Reviews in Food Science and Nutrition, 57(2):259-274, 2017.

WATERS, D. M.; ARENDT, E. K.; MORONI, A. V. Overview on the mechanisms of coffee germination and fermentation and their significance for coffee and coffee beverage quality. Critical Reviews in Food Science and Nutrition, 57(2):259-274, 2017.

XIN, X. et al. Reduced mitochondrial and ascorbateglutathione activity after artificial ageing in soybean seed. Journal of Plant Physiology, 171(2):140-147, 2014.

YIN, G. et al. Comprehensive mitochondrial metabolic shift during the critical node of seed ageing in rice. PloS One, 11(4):e0148013, 2016.

ZAIN, M. Z. M.; SHORI, A. B.; BABA, A. S. Composition and health properties of coffee bean. European Journal of Clinical and Biomedical Sciences, 3(5):97-100, 2017.

ZHANG, Y.; CHEN, B.; XU, Z. Involvement of reactive oxygen species in endosperm cap weakening and embryo elongation growth during lettuce seed germination. Journal of Experimental Botany, 65(12):3189-3200, 2014.

ZONTA, J. B. et al. Teste lercafé para sementes de cafeeiro com diferentes teores de água. Revista Brasileira de Sementes, 32(1):17-23, 2010. 